\title{
Bartonella: new explanations for old diseases
}

\author{
GILBERT GREUB and DIDIER RAOULT \\ Unité des Rickettsies, Faculté de Médecine, Université de la Méditerranée, Marseille, France
}

\section{Introduction}

Until recently, there were only two recognised human diseases caused by Bartonella spp.: trench fever due to B. quintana and Carrion's disease due to B. bacilliformis. Since then, Bartonella spp. have been recognised as causative agents of further human diseases, including bacillary angiomatosis, cat-scratch disease, chronic bacteraemia, chronic lymphadenopathy, meningoencephalitis, stellar retinitis, myelitis, granulomatous hepatitis, endocarditis, osteomyelitis and peliosis hepatitis [1] (Table 1). In parallel, the genus Bartonella, which until 1993 contained only one species ( $B$. bacilliformis), was broadly extended by reclassifying within it the genera Rochalimea [2] and Grahamella [3], and by the description of new Bartonella species (Fig. 1). Based on phylogenetic analysis of the $16 \mathrm{~S}$ rRNA sequences, the relatedness of Bartonella spp. to other alpha-2 Proteobacteria including Brucella spp., Afipia spp., Agrobacterium tumefaciens, Bradyrhizobium spp. and Bosea spp. has been demonstrated [2, 3]. Active research on the pathogenesis of Bartonella infections has been triggered by the increased number of species of Bartonella, the re-emergence of older disease due to Bartonella, such as the modern form of trench fever that affects alcoholics and homeless people [4], the recognition of the role of Bartonella in AIDSrelated diseases and the description of new clinical entities due to Bartonella spp. As a facultative intracellular bacterium, Bartonella interacts closely with its host cells. The study of these interactions gave an insight into some of the underlying virulence factors and pathogenic mechanisms, which may be common or specific to the host cell or to the Bartonella species studied, or both. Interactions of Bartonella spp. with (i) red blood cells and (ii) endothelial cells have been studied for several years, but (iii) bone marrow progenitor cells may also play a central role as a

Received 24 May 2002; accepted 4 June 2002.

Corresponding author: Professor D. Raoult (e-mail: didier.raoult @ medecine.univ-mrs.fr, gilbert.greub@medecine.univ-mrs.fr). sanctuary site in the pathogenesis of Bartonella (Fig. 2).

\section{The red blood cell \\ Infection of the red blood cell: a persistence and dissemination strategy}

Bartonella infections are vector-borne diseases characterised by a natural cycle, vectors and reservoir hosts [5]. Human pathogenicity is either related to natural infection ( $B$. quintana and $B$. bacilliformis) or to incidental infections (for other Bartonella spp.), acquired through contact with naturally infected mammals. Many Bartonella spp. have been shown to multiply and persist in red blood cells, sharing common persistence and dissemination strategies. Thus, $B$. henselae was found to infect cat red blood cells [68 ] and B. tribochorum those of rats [9], whereas $B$. quintana [10] and B. bacilliformis [11] were shown to invade human red blood cells. Bacteraemias were described even in healthy mammals, thus being one established exception to one of Koch's basic statements: 'Bacteria do not occur in the blood or tissues of healthy animals or humans' [12]. It was shown in the red blood cells of rats that the bacterial replication of $B$. tribocorum was regulated and stopped at a maximum of eight bacteria/cell [9]. The mechanism of regulation is unknown, but it prevents haemolysis and allows the persistence of Bartonella spp. within red blood cells. Disregulation of this mechanism, with uninterrupted multiplication of $B$. bacilliformis within red blood cells, might explain the rare acute haemolytic form of Carrion's disease (Oroya fever). However, as treatment of Bartonella with proteinase $\mathrm{K}$ has been shown to reduce the haemolytic activity of $B$. bacilliformis by $25 \%$, a bacterial protein may also be involved in Oroya fever-associated haemolysis [13]. The ability of Bartonella to persist in erythrocytes for long periods may have been driven by evolutionary constraints, as it increases its transmissibility by bloodsucking arthropods. This persistence, which explains the prolonged bacteraemia in symptomatic and asymptomatic subjects, and the occurrence of disseminated 
Table 1. Bartonella infections in man and related clinical entities

\begin{tabular}{lll}
\hline Disorder & Clinical presentation & Species involved \\
\hline $\begin{array}{l}\text { Carrion's disease } \\
\text { Oroya fever }\end{array}$ & $\begin{array}{l}\text { Acute febrile haemolytic anaemia or mild fever with body pain, nausea and } \\
\text { headache }\end{array}$ & B. bacilliformis \\
$\quad$ verruaga peruana & Exophytic or miliary skin eruption & B. bacilliformis \\
Trench fever & Relapsing fever, headache and body pain & B. quintana \\
Bacillary angiomatosis & Red and papular cutaneous lesions (with or without lymphadenopathy, & B. quintana, \\
& osteolysis, fever, weight loss) & B. henselae \\
Bacillary peliosis & Abdominal pain, fever, hepatosplenomegaly & B. henselae \\
Cat-scratch disease & Lymphadenopathy (with or without mild fever, body pain and headache) & B. henselae, \\
& & B. clarridgeiae? \\
ocular involvement & Conjunctival ulceration, stellar retinitis, neuroretinitis & B. henselae, \\
& & B. grahamii \\
Chronic bacteraemia & Fever, headache, leg pain and thrombocytopenia & B. quintana \\
Endocarditis & Fever, dyspnoea on exertion, bibasal lung rales, cardiac murmur, embolic & B. quintana, \\
& phenomena and vegetations & B. henselae, \\
& & B. vinsonii, \\
& & B. elizabethae \\
\hline
\end{tabular}

disease in the homeless (chronic bacteraemia) or AIDS patients (bacillary angiomatosis), may also be favoured by the intra-erythrocytic localisation which partially protects Bartonella from the immune system.

\section{Adherence to red blood cells}

B. bacilliformis possess polar flagella (Fig. 3) that have been shown to mediate erythrocyte adhesion [14]. This flagella-associated adhesion was supported by the poor adherence of non-motile variants [11] and has been confirmed by the reduction of the erythrocyte-binding ability of B. bacilliformis by $40-50 \%$ with antiflagellin antibodies [15] and by the $75 \%$ reduction in binding ability of a flagellin-minus mutant [16]. Importantly, erythrocyte adhesion was not fully restored by complementation of the minus-mutant [16]. As the other Bartonella spp. (except B. clarridgeiae) do not possess polar flagella and as the $B$. bacilliformis flagellin-minus mutant retained some adhesive ability, other important mechanisms are involved in adherence to red blood cells. One of these may be the bundleforming pili expressed at the surface of low-passaged $B$. henselae and B. bacilliformis cells, which have been implicated in the auto-agglutination propensity of Bartonella spp. [17]. Proteins exposed at the bacterial surface may also play a role in adhesion to erythrocytes, although no proteins able to interact with red blood cells have been identified yet. As adherence of $B$. bacilliformis to red blood cells is inhibited when the bacteria are pre-treated with N-ethyl maleimide, but is not inhibited when the erythrocytes are pre-treated with the same reagent [14], the red blood cell seems to play only a passive role in adherence. Membrane erythrocyte proteins, which bind B. bacilliformis passively, include spectrin and glycophorins A/B [18]. Enhanced binding of Bartonella to these proteins after treatment of erythrocytes with trypsin or neuraminidase has suggested a possible masking of binding site [18]. The fact that glycophorin $\mathrm{A} / \mathrm{B}$ is the major receptor on human erythrocytes for Plasmodium falciparum mero- zoites [19] suggests that this protein is also utilised by Bartonella to bind to erythrocytes.

\section{Invasion of red blood cells}

It has been speculated that the binding of Bartonella to spectrin may be a first step necessary to alter the erythrocyte membrane for internalisation of Bartonella cells [18]. This hypothesis is supported by the role of spectrin in the maintenance of erythrocyte shape and membrane integrity and deformability [18] and by the fact that proteases from $P$. falciparum were shown to cleave erythrocyte cytoskeletal components and spectrin [20]. A bacterial protein named deformin also appeared to be involved, at least for B. bacilliformis, in the formation of pits and trenches in the red cell membranes $[11,21]$, that may favour both colonisation and entry into the cell [17]. This molecule, initially thought to be a protein, seems to be a small hydrophobic molecule with affinity for albumin, although the effector mechanism remains to be elucidated [22]. The presence of a homologue of the deformin of $B$. bacilliformis that also led to the invagination of red blood cells, although less pronounced, has been identified in $B$. henselae culture supernate [23], suggesting that the deformin-mediated invasion mechanism might be shared between several Bartonella species.

At the molecular level, the genes of the invasionassociated locus ( $\mathrm{ial}$ ) identified in $B$. bacilliformis have been shown to confer an invasive phenotype to minimally invasive Escherichia coli strains [24]. The ial contains two genes named ialA and ialB. Immediately upstream lies a gene encoding a carboxy-terminal protease, $\operatorname{ctp} A$, and another gene encoding the filament A polypeptide (FilA) [17,25]. Downstream lie two open reading frames that do not share homology with other species $[17,25]$. These six genes are thought to constitute a pathogenicity gene cluster, as (i) both ialA and $i a l B$ genes are needed to confer the invasive phenotype to E. coli; (ii) the gene encoding for the 


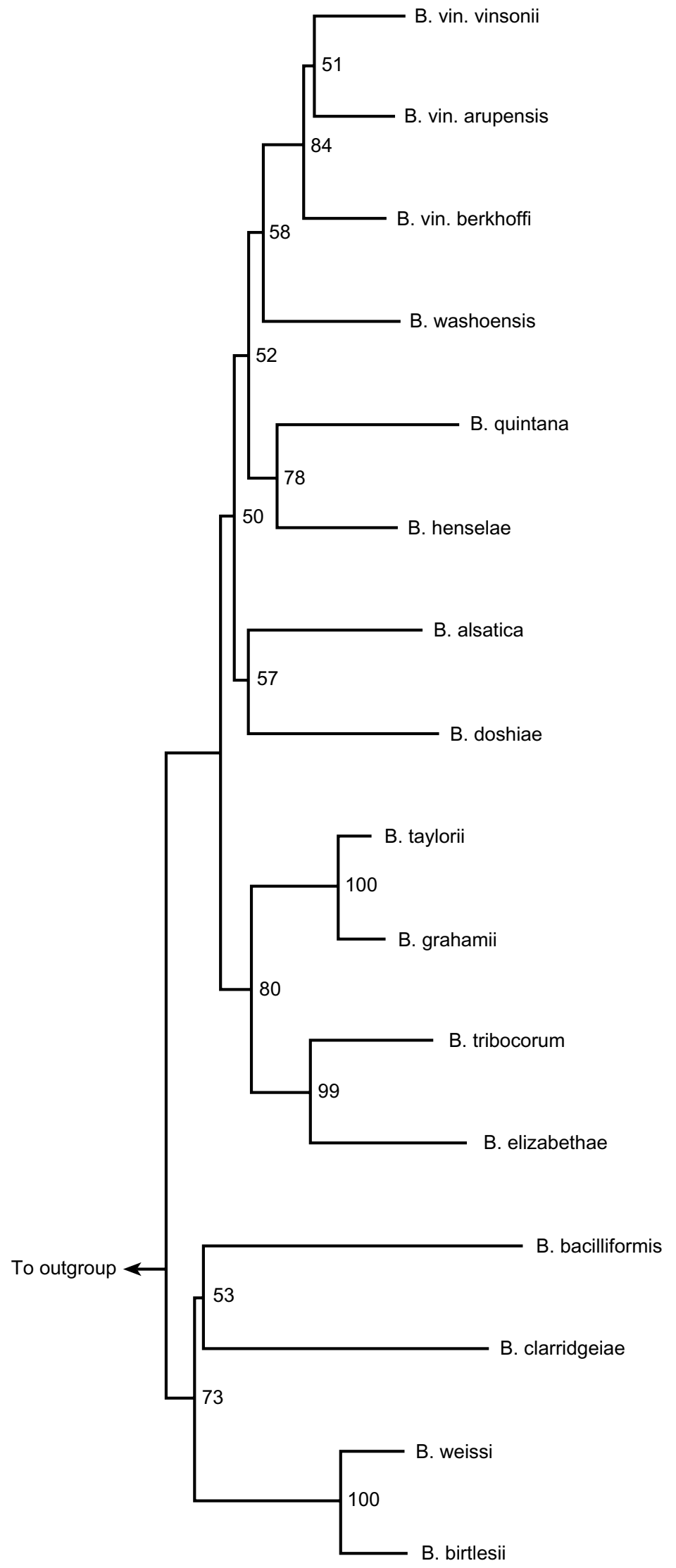

0.1

Fig. 1. Neighbour-joining tree resulting from comparison of sequences of groEL encoding genes of most Bartonella spp. identified to date. The values at each node represent the percentage of times each branch was found in 100 bootstrap replicates. 

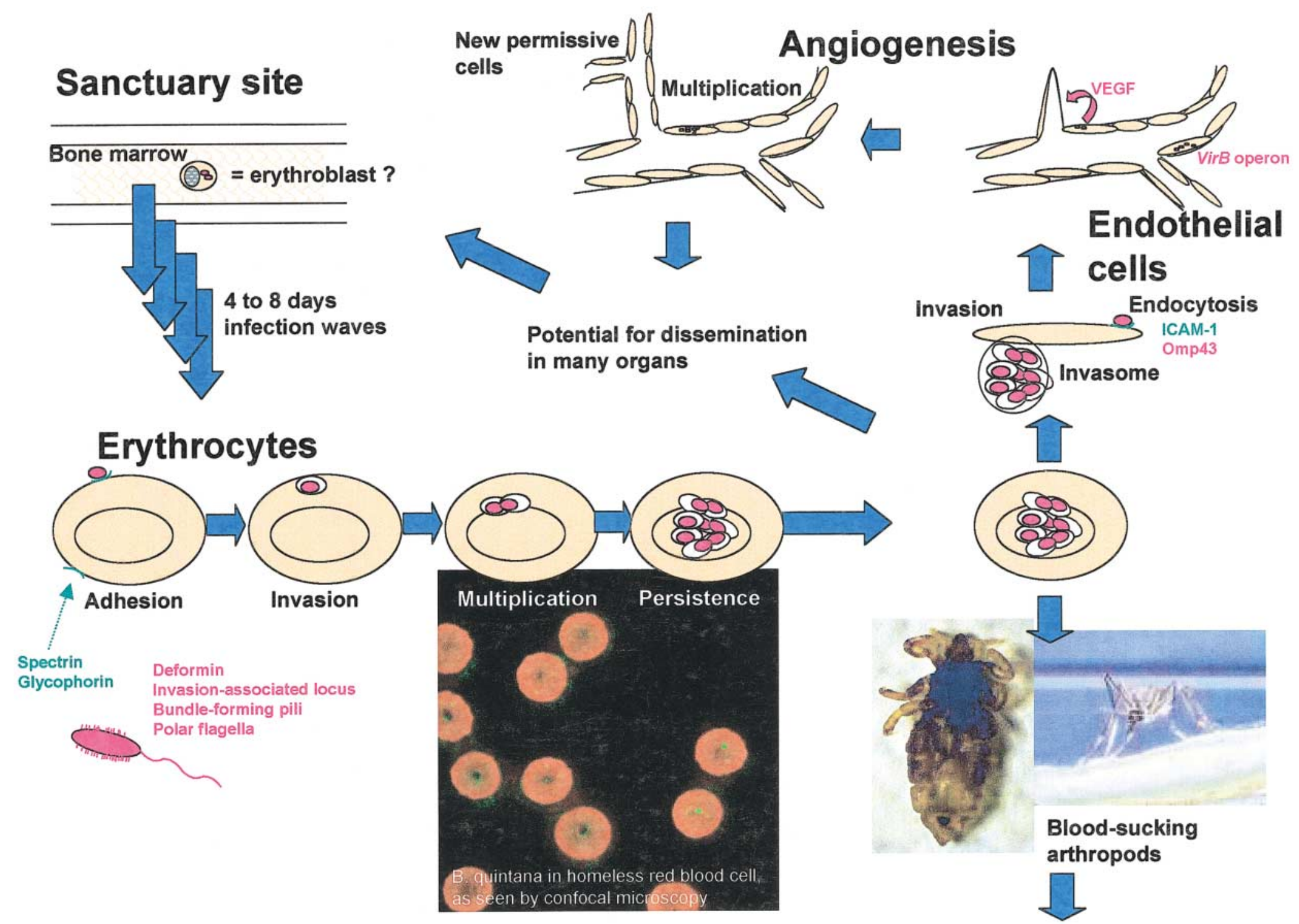

Transmission

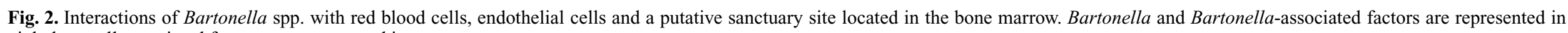
pink, host cell-associated factors are represented in green. 


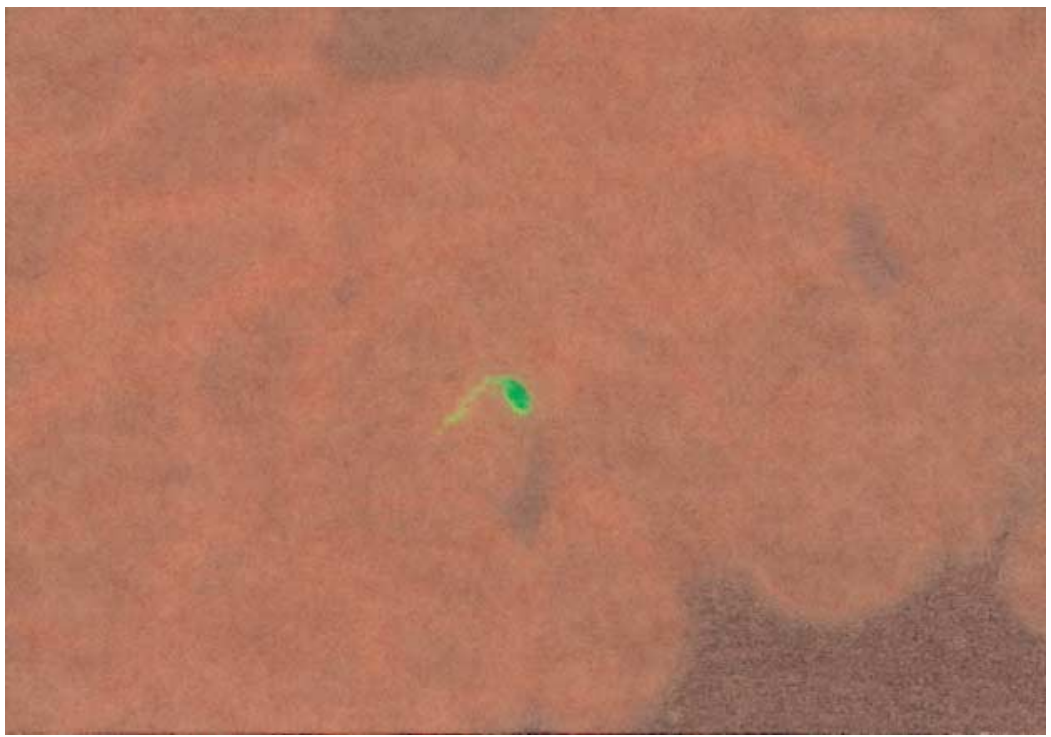

Fig. 3. B. bacilliformis and its polar flagella, within human erythrocytes, as seen by confocal microscopy. (Courtesy of J. M. Rolain, Marseille.)

adhesion and invasion locus (Ail) protein of Yersinia enterocolitica, which is implicated in host cell attachment and invasion, shares $60 \%$ amino acid similarity with that encoded by $i a l B$; and (iii) FilA exhibits amino acid similarity with various filamentous proteins including the M1 of Streptococcus pyogenes, involved in adhesion and invasion [17]. Furthermore, CtpA might also be involved in virulence, as a C-terminal protease of Salmonella typhimurium enhances intramacrophage survival [26]. More importantly, several genes of this cluster have been sequenced in other Bartonella spp., and also in other facultatively intracellular bacteria, suggesting that some of the adhesion, invasion and persistence mechanisms used by Bartonella may be common to these species. Thus, the amino acid sequence of $B$. bacilliformis ialA shared $73 \%$ homology with that of B. clarridgeiae and $49 \%$ with that of Brucella melitensis, another member of the Rhizobium group, while the amino acid sequence of $B$. bacilliformis CtpA shared $81 \%$ homology with that of B. quintana and $71 \%$ with that of Br. melitensis (homology analysis performed with ClustalW) [27]. Whether ialA and ialB may explain the peculiar tropism of Bartonella for red blood cells remains to be defined. The role played by CtpA, FilA and both additional orphan open-reading frames remains also to be clarified. A role in quorum sensing, i.e., regulation of the intra-erythrocytic growth of Bartonella may be possible. In conclusion, it appears that specific (polar flagella) and common (deformin, invasion-associated locus) mechanisms have been developed by the different Bartonella spp. to adhere to and invade the red blood cells.

\section{Angiogenesis}

Apart from their tropism for red blood cells, a second typical pathogenic feature of Bartonella spp. is their ability to trigger angiogenesis. Such pathological angiogenesis is observed in bacillary angiomatosis and peliosis [28-31].

\section{An unknown protein}

The first experimental evidence that Bartonella-related angiogenesis may be due to a protein was afforded by Garcia et al. in 1990 [32]. They demonstrated that $B$. bacilliformis extracts possess an activity that stimulates endothelial cell proliferation up to three times that of a control [32]. The factor, which was found to be specific for endothelial cells and was larger than 12-14 kDa (not dialysed), was thought to be a protein because it was heat sensitive and precipitated with ammonium sulphate $45 \%$ [32]. B. bacilliformis extracts were also reported to stimulate the production of tissue plasminogen [32]. Live bacteria were later shown to increase both parameters (angiogenesis and tissue plasminogen production) in a fashion similar to the homogenates of $B$. bacilliformis [33]. In 1994, Conley demonstrated in a similar in-vitro model that $B$. henselae induces an angiogenic factor, whose susceptibility to trypsin also suggests that the factor may be a protein. More recently, it has been shown that this factor may be secreted by $B$. henselae [34], indicating that $B$. henselae may induce endothelial cell proliferation independently of bacterial invasion. The dramatic effect of erythromycin on the cutaneous lesions of bacillary angiomatosis $[35,36]$ may be due to inhibition of the production of the proteic angiogenic factor(s), as erythromycin is known to inhibit protein production at the ribosomal level. An angiogenesis-based effect would better explain the rapidity of its effect and its lack of a sustained response than a direct microbicidal one.

\section{Vascular endothelial growth factor (VEGF)}

VEGF, angiopoietins and ephrins were proved to be 
critical and specific for blood vessel formation [37]. Recently, Kempf et al. demonstrated that B. henselae induce EA.hy 926 cells (permanent endothelial cell line expressing factor VIII) to produce VEGF, which in turn was able to stimulate the proliferation of endothelial cells and the growth of $B$. henselae [38]. In the same study, Kempf et al. showed that the administration of VEGF-neutralising antibodies reduced endothelial proliferation by $50 \%$ [38], suggesting that other factors are involved, such as angiopoietins, ephrins or the yet unknown proteic factor discussed above.

Importantly, VEGF not only induces endothelial proliferation but also cell migration through several pathways that include the activation of a small GTP-ase RhoA, which is associated with phosphorylation of myosin light chain [39]. This may easily explain why Bartonella-associated angiogenesis is also characterised by altered spatial organisation within the monolayer and changes in cell morphology due to cytoskeleton reorganisation [40]. However, the impaired migratory ability of Bartonella-infected endothelial cells [41] was more surprising. This impaired mobility might result from the formation of thick robust stress fibres, probably via the activation of RhoA, as suggested by an inactivation assay [41]. Thus, the cells that effectively participate in angiogenesis are probably uninfected endothelial cells that respond to VEGF produced by the infected ones. B. henselae not only promotes the formation of new permissive cells but also protects the infected cells from apoptosis. Indeed, Bartonella suppress both early and late events in apoptosis, namely caspase activation and DNA fragmentation [42]. This anti-apoptotic effect, found to be specific for endothelial cells [42], may be mediated at least partially by VEGF, which is known to protect the cells from apoptosis [43].

\section{Peliosis hepatitis}

Peliosis hepatitis, which corresponds histologically to multiple blood-filled cystic spaces often communicating with the hepatic sinusoids, was initially thought to be induced by viruses [44]. Similar lesions were later observed in mice or rats exposed to various drugs or toxins, including phalloidine and oxazepam $[45,46]$ and reported in patients with advanced cancer or receiving anabolic steroids. The Bartonella-associated peliosis hepatitis, associated with HIV infection, differs from that of classical peliosis hepatitis by the additional presence of clumps of bacteria [47]. Recently, while studying the ability of VEGF to block tumour regression, Wong et al. observed that mice implanted with VEGF-expressing tumours sustained high morbidity and mortality that were out of proportion to the tumour burden. High serum levels of VEGF were associated with a lethal hepatic syndrome characterised by massive sinusoidal dilatation and endothelial cell proliferation and apoptosis [48]. A striking reversal of VEGF-induced liver pathology was achieved by surgical excision of VEGF-secreting tumours or by systemic administration of a potent VEGF antagonist [48]. As this VEGF-induced syndrome resembles cancer and Bartonella-induced peliosis hepatitis, the bacillary peliosis hepatitis may be directly due to the VEGF produced by the infected endothelial cells and by other infected cells that are known to secrete VEGF, such as erythroblasts [49].

\section{Placenta growth factor}

The placenta growth factor (PIGF) is analogous to VEGF and is secreted by the placenta and erythroblasts $[37,49]$. Its effect on Bartonella multiplication remains to be defined, as does the role played by Bartonella in its production. However, the presence of vascular lesions in the maternal placenta of mice infected experimentally with $B$. birtlesii [50], and the role played by VEGF in Bartonella pathogenesis [38], suggest that PIGF might be involved in the genesis of the reproductive disorders observed by Boulouis et al. in infected mice.

\section{Endothelial cells}

The Bartonella-endothelial cell interaction is not restricted to angiogenesis stimulation. Thus, (i) invasion of endothelial cells was described for B. quintana [51], B. henselae [52] and B. bacilliformis [53], and (ii) a pro-inflammatory activation of endothelial cells was postulated, which is thought to be a result of receptorligand interactions between the activated endothelium and circulating neutrophils [54].

\section{Adherence to endothelial cells}

The bacterial ligands that may be involved in adherence may include bundle-forming pili (see above) and several outer-membrane proteins (OMPs). Of the nine proteins located in the outer membrane of $B$. henselae, five were shown to bind human umbilical vein endothelial cells [55]. Of these, a 43-kDa protein (Omp43), that exhibits a similar amino acid sequence to the Omp2b porin of Brucella spp., was shown to have especially high affinity with endothelial cells, suggesting that it may play a major role in Bartonella pathogenesis $[55,56]$. The endothelial receptors involved in Bartonella adhesion may include intercellular adhesion molecule-1 (ICAM-1), which has been shown to be enriched especially at the tips of the protrusions of the endothelial membrane [52]. Interestingly, endothelial adhesion molecules (ICAM-1 and Eselectin) expression is upregulated via NF- $\kappa \mathrm{B}$ translocation, induced by B. henselae [52].

\section{Invasion of endothelial cells}

Endothelial cells are invaded by two mechanisms: (i) endocytosis of bacteria, similar to that present in other 
intracellular clades, and (ii) the engulfment of clustered bacteria by a unique host cell structure called the invasome [52]. Invasion is associated with cytoskeletal re-arrangements, themselves induced by Bartonella via Rho GTPase signalling [41].

\section{Type IV secretion system and the VirB operon}

Type IV secretion systems consist of a multiprotein channel that transports DNA or protein from bacteria to host cell. Such a system is present in A. tumefaciens, another alpha-2 proteobacterium that parasitises plants. A gene cluster, the virB operon of $A$. tumefaciens, plays a critical role in the formation of the channel through which the transfer of oncogenic T-DNA occurs, resulting in tumour formation [58]. Type IV secretion systems coded by the virB operon are also present in Br. suis and Bordetella pertussis, where they appear to be required for survival in host macrophages and exportation of the pertussis toxin, respectively $[59,60]$. Recently, Padmalayan et al. discovered that the gene encoding an immunogenic $17-\mathrm{kDa}$ antigen of $B$. henselae was located within the vir $B$ operon of $B$. henselae [61]. The virB operon of $B$. henselae encodes 10 genes, of which eight share significant homology to those of $A$. tumefaciens, suggesting that it encodes for a type IV secretion system. Interestingly, no homologues of the gene encoding the immunogenic $17-\mathrm{kDa}$ antigen are present outside Bartonella spp. [61]. Its expression is stimulated by endothelial cells [62]. Although the molecule that may be transferred to the host cell remains to be defined, some have speculated that it may be involved in the production of VEGF by the endothelial cells.

\section{Activation of endothelial cells}

A pro-inflammatory activation of endothelial cells was postulated, which is thought to be a result of receptorligand interactions between the activated endothelium and circulating neutrophils [54]. This is supported by the recent demonstration that $B$. henselae itself and $B$. henselae-derived OMPs induce an NF- $\kappa \mathrm{B}$-dependent upregulation of E-selectin and ICAM-1 in endothelial cells, which in turn results in enhanced polymorphonuclear rolling and adhesion [57].

\section{Primary niche}

In the rat model of $B$. tribochorum infection, the presence of periodic erythrocyte infection waves has been demonstrated [9], that echo the 5-day periodicity of the 'Quintan fever'. The fact that Bartonella parasitise erythrocytes without leading to haemolysis, with the exception of $B$. bacilliformis, suggests that the re-infection waves are due to the liberation of the bacteria from a distant sanctuary site [54]. This unknown primary niche might be the endothelial cells, as suggested by Dehio [54]. However, a number of hints suggest that the primary niche or sanctuary site might instead be located in the bone marrow, as follows. (i) Although, in vitro, Bartonella is able to enter various cells, including macrophages [63], only erythrocytes and endothelial cells are permissive to Bartonella in vivo. The cells that play the role of primary niche should thus share some characteristics common to erythrocytes and endothelial cells. Candidates are mainly the cells that are issued by differentiation of the haemangioblast, the common precursor of both erythrocytes and endothelial cells. These include mainly angioblasts and erythroblasts. (ii) The fact that erythroblasts express VEGF [49], a factor known to enhance Bartonella replication [38]. (iii) All organs involved in bacillary angiomatosis could potentially play the role of sanctuary, including brain, penis, vulva, cervix, muscle and bone marrow [64-68]. However, after skin, bone is the second most frequent site, and bone lesions of bacillary angiomatosis are characterised by well circumscribed osteolysis, that is often painful and usually affects long bones [69]. Pain pattern and osteolysis echo those found in mastocytosis and multiple myeloma, suggesting that bone marrow cells may be infected by Bartonella. (iv) The outstanding features of trench fever are pain and tenderness in the shins and relapsing fever [70]. Many subjects also present only with painful shins, which were often, in the absence of fever, wrongly attributed to flat feet or rheumatism due to prolonged standing in mud and water [70]. This suggests that $B$. quintana may involve the bone marrow in trench fever patients. (v) The fact that bone marrow cells are highly permissive to $\mathrm{Br}$. melitensis, a phylogenetically close relative of Bartonella spp. and to many other intracellular pathogens.

\section{Conclusions}

Future research should especially be aimed at defining the factors (i) determining the host specificity (especially for human-specific species), (ii) involved in erythrocyte and endothelial cell infection, and (iii) controlling Bartonella-associated angiogenesis. Moreover, the location in the host of a Bartonella sanctuary, if any, which could be responsible for the observed relapses of intra-erythrocytic infections should be identified. Bone marrow progenitors such as erythroblasts might be a potential candidate but this should be investigated further.

\section{References}

1. Jacomo V, Kelly PJ, Raoult D. Natural history of Bartonella infections (an exception to Koch's postulates). Clin Diagn Lab Immunol 2002; 9: 8-18.

2. Brenner DJ, O'Connor SP, Winkler HH, Steigerwalt AG. Proposals to unify the genera Bartonella and Rochalimaea, with descriptions of Bartonella quintana comb. nov., Bartonella vinsoni comb. nov., Bartonella henselae comb. nov., and Bartonella elizabethae comb. nov., and to remove the family 
Bartonellaceae from the order Rickettsiales. Int $J$ Syst Bacteriol 1993; 43: 777-786.

3. Birtles RJ, Harrison TG, Saunders NA, Molyneux DH. Proposals to unify the genera Grahamella and Bartonella, with descriptions of Bartonella talpae comb. nov., Bartonella peromysci comb. nov., and three new species, Bartonella grahamii sp. nov., Bartonella taylorii sp. nov., and Bartonella doshiae sp. nov. Int J Syst Bacteriol 1995; 45: 1-8.

4. Brouqui P, Lascola B, Roux V, Raoult D. Chronic Bartonella quintana bacteremia in homeless patients. N Engl J Med 1999; 340: $184-189$.

5. Breitschwerdt EB, Kordick DL. Bartonella infection in animals: carriership, reservoir potential, pathogenicity, and zoonotic potential for human infection. Clin Microbiol Rev 2000; 13: 428-438.

6. Kordick DL, Breitschwerdt EB. Intraerythrocytic presence of Bartonella henselae. J Clin Microbiol 1995; 33: 1655-1656.

7. Mehock JR, Greene CE, Gherardini FC, Hahn TW, Krause DC. Bartonella henselae invasion of feline erythrocytes in vitro. Infect Immun 1998; 66: 3462-3466.

8. Rolain JM, La Scola B, Liang Z, Davoust B, Raoult D Immunofluorescent detection of intraerythrocytic Bartonella henselae in naturally infected cats. J Clin Microbiol 2001; 39: 2978-2980.

9. Schülein R, Seubert A, Gilles C et al. Invasion and persistent intracellular colonization of erythrocytes: a unique parasitic strategy of the emerging pathogen Bartonella. J Exp Med 2001; 193: 1077-1086.

10. Rolain JM, Foucault C, Guieu R, La Scola B, Brouqui P, Raoult D. Bartonella quintana in human erythocytes. Lancet 2002; 360: 226-228.

11. Benson LA, Kar S, McLaughlin G, Ihler GM. Entry of Bartonella bacilliformis in erythrocytes. Infect Immun 1986; 54: 347-353.

12. Brock TD. Robert Koch, a life in medicine and bacteriology. Washington, DC, ASM Press. 1999.

13. Hendrix LR. Contact-dependent hemolytic activity distinct from deforming activity of Bartonella bacilliformis. FEMS Microbiol Lett 2000; 182: 119-124.

14. Walker TS, Winkler HH. Bartonella bacilliformis: colonial types and erythrocyte adherence. Infect Immun 1981; 31: 480-486.

15. Scherer DC, DeBuron-Connors I, Minnick MF. Characterization of Bartonella bacilliformis flagella and effect of antiflagellin antibodies on invasion of human erythrocytes. Infect Immun 1993; 61: 4962-4971.

16. Battisti JM, Minnick MF. Development of a system for genetic manipulation of Bartonella bacilliformis. Appl Environ Microbiol 1999; 65: 3441-3448.

17. Minnick MF, Anderson BE. Bartonella interactions with host cells. Subcell Biochem 2000; 33: 97-123.

18. Buckles EL, McGinnis Hill E. Interaction of Bartonella bacilliformis with human erythrocyte membrane proteins. Microb Pathog 2000; 29: 165-174.

19. Perkins ME. Surface proteins of Plasmodium falciparum merozoites binding to the erythrocyte receptor, glycophorin. $J$ Exp Med 1984; 160: 788-798.

20. Deguercy A, Hommel M, Schrevel J. Purification and characterization of 37-kilodalton proteases from Plasmodium falciparum and Plasmodium berghei which cleave erythrocyte cytoskeleton. Mol Biochem Parasitol 1990; 38: 233-244.

21. Mernaugh G, Ihler GM. Deformation factor: an extracellular protein synthesized by Bartonella bacilliformis that deforms erythrocyte membranes. Infect Immun 1992; 60: 937-943.

22. Derrick SC, Ihler GM. Deformin, a substance found in Bartonella bacilliformis culture supernatants, is a small hydrophobic molecule with an affinity for albumin. Blood Cell Mol Dis 2001; 27: 1013-1019.

23. Iwaki-Egawa S, Ihler GM. Comparison of the abilities of proteins from Bartonella bacilliformis and Bartonella henselae to deform red cell membranes and to bind to red cell ghost proteins. FEMS Microbiol Lett 1997; 157: 207-217.

24. Mitchell SJ, Minnick MF. Characterization of a two-gene locus from Bartonella bacilliformis associated with the ability to invade human erythrocytes. Infect Immun 1995; 63: $1552-1562$

25. Mitchell SJ, Minnick MF. A carboxy-terminal processing protease gene is located immediately upstream of the invasion-associated locus from Bartonella bacilliformis. Micro- biology 1997; 143: 1221-1233.

26. Bäumler AJ, Kusters JG, Stojiljkovic I, Heffron F. Salmonella typhimurium loci involved in survival within macrophages. Infect Immun 1994; 62: 1623-1630.

27. Thompson JD, Higgins DG, Gibson TJ. CLUSTAL W: improving the sensitivity of progressive multiple sequence alignment through sequence weighting, position-specific gap penalties and weight matrix choice. Nucleic Acids Res 1994; 22: 4673-4680.

28. Stoler MH, Bonfiglio TA, Steigbigel RT, Pereira M. An atypical subcutaneous infection associated with acquired immune deficiency syndrome. Am J Clin Pathol 1983; 80: 714-718.

29. Leboit PE, Berger TG, Egbert BM, Beckstead JH, Yen TS, Stoler MH. Bacillary angiomatosis. The histopathology and differential diagnosis of a pseudoneoplastic infection in patients with human immunodeficiency virus disease. $A m J$ Surg Pathol 1989; 13: 909-920.

30. Tappero JW, Koehler JE, Berger TG et al. Bacillary angiomatosis and bacillary splenitis in immuno-competent adults. Ann Intern Med 1993; 118: 363-365.

31. Kemper CA, Lombard CM, Deresinski SC, Tompkins LS. Visceral bacillary epithelioid angiomatosis: possible manifestations of disseminated cat scratch disease in the immunocompromised host: a report of two cases. Am J Med 1990; 89: $216-222$.

32. Garcia FU, Wojta J, Broadley KN, Davidson JM, Hoover RL. Bartonella bacilliformis stimulates endothelial cells in vitro and is angiogenic in vivo. Am J Pathol 1990; 136: 1125-1135.

33. Garcia FU, Wojta J, Hoover RL. Interactions between live Bartonella bacilliformis and endothelial cells. J Infect Dis 1992; 165: 1138-1141.

34. Maeno N, Oda H, Yoshiie K, Rezwanul Whahid M, Fujimura T, Matayoshi S. Live Bartonella henselae enhances endothelial cell proliferation without direct contact. Microb Pathog 1999; 27: 419-427.

35. Koehler JE, Sanchez MA, Garrido CS et al. Molecular epidemiology of Bartonella infections in patients with bacillary angiomatosis-peliosis. $N$ Engl J Med 1997; 337: 1876-1883.

36. Koehler JE, Tappero JW. Bacillary angiomatosis and bacillary peliosis in patients infected with human immunodeficiency virus. Clin Infect Dis 1993; 17: 612-624.

37. Yancopoulos GD, Davis S, Gale NW, Rudge JS, Wiegand SJ, Holash J. Vascular-specific growth factors and blood vessel formation. Nature 2000; 407: 242-248.

38. Kempf VAJ, Volkmann B, Schaller M et al. Evidence of a leading role for VEGF in Bartonella hemselae - induced endothelial cell proliferation. Cell Microbiol 2001; 3: 623-632.

39. Rousseau S, Houle F, Huot J. Integrating the VEGV signals leading to actin-based motility in vascular endothelial cells. Trends Cardiovasc Med 2000; 10: 321-327.

40. Palmari J, Teysseire N, Dussert C, Raoult D. Image cytometry and topographical analysis of proliferation of endothelial cells in vitro during Bartonella (Rochalimaea) infection. Anal Cell Pathol 1996; 11: 13-30.

41. Verma A, Davis GE, Ihler GM. Formation of stress fibres in human endothelial cells infected with Bartonella bacilliformis is associated with altered morphology, impaired migration and defects in cell morphogenesis. Cell Immunol 2001; 3: 169-180.

42. Kirby JE, Nekorchuck DM. Bartonella-associated endothelial proliferation depends on inhibition of apoptosis. Proc Natl Acad Sci USA 2002; 99: 4656-4661.

43. Marx PT, Mulder AB, Van Den Bergh FA, Overbeeke R, Haanen C, Vermes I. Apoptosis inducers, endotoxin and Fasligation enhance the expression of vascular endothelial growth factor in human endothelial cells. Endothelium 1999; 6: $335-340$.

44. Bergs VV, Scotti TM. Virus-induced peliosis hepatitis in rats. Science 1967; 158: 377-378.

45. Tuchweber B, Kovacs K, Khandekar JD, Garg BD. Peliosis-like changes induced by phalloidin in the rat liver. $J$ Med 1973; 4: $327-345$.

46. Fox KA, Lahcen RB. Liver-cell adenomas and peliosis hepatitis in mice associated with oxazepam. Res Commun Chem Pathol Pharmacol 1974; 8: 481-488.

47. Perkocha LA, Geaghan SM, Yen TSB et al. Clinical and pathological features of bacillary peliosis hepatitis in association with human immunodeficiency virus infection. $N$ Engl J 
Med 1990; 323: 1581-1586.

48. Wong AK, Alfert M, Castrillon DH et al. Excessive tumorelaborated VEGF and its neutralization define a lethal paraneoplastic syndrome. Proc Natl Acad Sci USA 2001; 98: 7481-7486.

49. Tordjman R, Delaire S, Plouët J et al. Erythroblasts are a source of angiogenic factors. Blood 2001; 97: 1968-1974.

50. Boulouis HJ, Barrat F, Bermond D et al. Kinetics of Bartonella birtlesii infection in experimentally infected mice and pathogenic effect on reproductive functions. Infect Immun 2001; 69: 5313-5317.

51. Brouqui P, Raoult D. Bartonella quintana invades and multiplies within endothelial cells in vitro and in vivo and forms intracellular blebs. Res Microbiol 1996; 147: 719-731.

52. Dehio C, Meyer M, Berger J, Schwarz H, Lanz C. Interaction of Bartonella henselae with endothelial cells results in bacterial aggregation on the cell surface and the subsequent engulfment and internalisation of the bacterial aggregate by a unique structure, the invasome. J Cell Sci 1997; 110: 2141-2154.

53. Blumwald E, Fortin MG, Rea PA, Verma DPS, Poole RJ. Presence of host-plasma membrane type $\mathrm{H}^{+}$-ATPase in the membrane envelope enclosing the bacteroids in soybean root nodules. Plant Physiol 1985; 78: 665-672.

54. Dehio C. Bartonella interactions with endothelial cells and erythrocytes. Trends Microbiol 2001; 9: 279-285.

55. Burgess AWO, Anderson BE. Outer membrane proteins of Bartonella henselae and their interaction with human endothelial cells. Microb Pathog 1998; 25: 157-164.

56. Burgess AWO, Paquet J-Y, Letesson J-J, Anderson BE. Isolation, sequencing and expression of Bartonella henselae omp43 and predicted membrane topology of the deduced protein. Microb Pathog 2000; 29: 73-80.

57. Fuhrmann $\mathrm{O}$, Arvand $\mathrm{M}$, Göhler $\mathrm{A}$ et al. Bartonella henselae induces NF- $\kappa$ B-dependent upregulation of adhesion molecules in cultured human endothelial cells: possible role of outer membrane proteins as pathogenic factors. Infect Immun 2001; 69: $5088-5097$.

58. Zupan JR, Ward D, Zambryski P. Assembly of the $\operatorname{Vir} B$ transport complex for DNA transfer from Agrobacterium tumefaciens to plant cells. Curr Opin Microbiol 1998; 1:
649-655.

59. Sieira R, Comerci DJ, Sanchez DO, Ugalde RO. A homologue of an operon required for DNA transfer in Agrobacterium is required in Brucella abortus for virulence and intracellular multiplication. J Bacteriol 2000; 182: 4849-4855.

60. Weiss AA, Johnson FD, Burns DL. Molecular characterization of an operon required for pertussis toxin secretion. Proc Natl Acad Sci USA 1993; 90: 2970-2974.

61. Padmalayam I, Karem K, Baumstark B, Massung R. The gene encoding the $17-\mathrm{kDa}$ antigen of Bartonella henselae is located within a cluster of genes homologous to the virB virulence operon. DNA Cell Biol 2000; 19: 377-382.

62. Schmiederer M, Arcenas R, Widen R, Valkov N, Anderson B. Intracellular induction of the Bartonella henselae virB operon by human endothelial cells. Infect Immun 2001; 69: 6495-6502.

63. Musso $\mathrm{T}$, Badolato $\mathrm{R}$, Ravarino $\mathrm{D}$ et al. Interaction of Bartonella henselae with the murine macrophage cell line J774: infection and proinflammatory response. Infect Immun 2001; 69: 5974-5980

64. Spach DH, Panther LA, Thorning DR, Dunn JE, Plorde JJ, Miller RA. Intracerebral bacillary angiomatosis in patients infected with human immunodeficiency virus. Ann Intern Med 1992; 116: 740-742.

65. Blanche P, Bachmeyer C, Salmon-Ceron D, Sicard D. Muscular bacillary angiomatosis in AIDS. $J$ Infect 1998; 37: 193.

66. Long SR, Whitfeld MJ, Eades C, Koehler JE, Korn AP, Zaloudek CJ. Bacillary angiomatosis of the cervix and vulva in a patient with AIDS. Obstet Gynecol 1996; 88: 709-711.

67. Eden CG, Marker A, Pryor JP. Human immunodeficiency virus-related bacillary angiomatosis of the penis. $\mathrm{Br} J \mathrm{Urol}$ 1996; 77: 323-324

68. Fagan WA, Skinner SM, Ondo A et al. Bacillary angiomatosis of the skin and bone marrow in a patient with HIV infection. J Am Acad Dermatol 1995; 32: 510-512.

69. Baron AL, Steinbach LS, LeBoit PE, Mills CM, Gee JH, Berger TG. Osteolytic lesions and bacillary angiomatosis in HIV infection: radiologic differentiation from AIDS-related Kaposi sarcoma. Radiology 1990; 177: 77-81.

70. Swift HF. Trench fever. The Harvey Lecture 1919/1920, series $\mathrm{XV}, 58-86$ 